\title{
Emerging details about COVID-19 and chronology of the pandemic in Turkey
}

\author{
Muammer GÖNCÜOĞLU ${ }^{1, a}{ }^{凶}$, Naim Deniz AYAZ ${ }^{2, b}$, Görkem CENGIZZ $^{1, \mathrm{c}}$, Bahar ONARAN ${ }^{1, \mathrm{~d}}$, \\ Gizem ÇUFAOĞLU ${ }^{2, e}$
}

\author{
${ }^{1}$ Ankara University, Faculty of Veterinary Medicine, Department of Food Hygiene and Technology, Ankara; ${ }^{2}$ Kırıkkkale University, \\ Faculty of Veterinary Medicine, Department of Food Hygiene and Technology, Kırıkkale, Turkey. \\ aORCID: 0000-0001-7245-1941; ' ${ }^{\mathrm{a} O R C I D: ~ 0000-0003-2219-2368 ; ~ ' ~ O R C I D: ~ 0000-0001-9853-565 X ; ~}$ \\ ${ }^{\mathrm{d} O R C I D: 0000-0002-3515-7548 ;}{ }^{\mathrm{e}}$ ORCID: 0000-0001-8639-532X
}

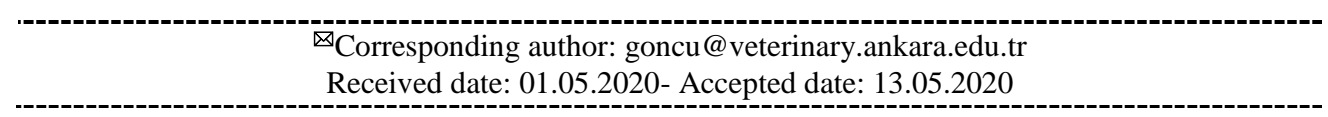

\begin{abstract}
Coronaviruses are found in all mammalian and avian species. Due to its mild infection on upper respiratory tract, this virus was not considered as a serious human pathogen until the outbreaks of SARS-CoV and MERS-CoV in 2002 and 2012 , respectively. Recently the third and the biggest outbreak of coronavirus "COVID-19" or "SARS-CoV-2" has erupted and the world is now in a struggle to combat this disease. Although everything has not yet been fully clarified about this new type of virus, the data obtained from the studies conducted so far provides guidance on how to deal with SARS-CoV-2. In this context, this review provides information about pathogenesis, clinical symptoms, presence in animals, potential transmission routes of SARS-CoV-2 as well as the detection methods used in the world and Turkey.
\end{abstract}

Keywords: Coronavirus, COVID-19, fecal-oral transmission, gastrointestinal symptoms, SARS-CoV-2, Turkey.

\section{COVID-19 hakkında ortaya çıkan bilgiler ve Türkiye'de pandeminin kronolojisi}

Özet: Koronavirüsler tüm memeli ve kuş türlerinde bulunmaktadır. Üst solunum yollarında meydana getirdiği hafif enfeksiyon nedeniyle, bu virüs 2002 yılına SARS-CoV ve 2012 yılında MERS-CoV salgınları patlak verene kadar ciddi bir insan patojeni olarak düşünülmemiştir. Bugün ise dünya, yakın geçmişte meydana gelen üçüncü ve en büyük koronavirüs salgını olan "COVID-19” veya "SARS-CoV-2" ile mücadele içindedir. Bu yeni tip virüs hakkında henüz her şey tam olarak açığa kavuşmuş olmasa da, şimdiye kadar yapılan çalışmalardan elde edilen veriler SARS-CoV-2 ile nasıl başa çıkılacağı konusunda bizlere rehberlik etmektedir. Bu derlemede, SARS-CoV-2'nin patogenezi, klinik semptomları, hayvanlarda bulunuşu, potansiyel bulaşma yolları ile dünya ve Türkiye'de kullanılan tespit yöntemleri hakkında bilgi verilmektedir.

Anahtar sözcükler: COVID-19, fekal-oral bulaşma, gastrointestinal semptomlar koronavirus, SARS-CoV-2, Türkiye.

\section{Introduction to SARS-CoV-2}

Coronaviruses are found in all mammalian and avian species (26). Due to its mild infection on upper respiratory tract, this virus was not considered as a serious human pathogen before 2003 (12). The first zoonotic entry of a coronavirus into the human population happened in 2002 with Severe Acute Respiratory Syndrome Coronavirus (SARS-CoV) which belongs to the lineage $2 b$ Betacoronavirus. The disease resulted in a global pandemic with 8400 cases and 800 deaths (45). Ten years later, a second outbreak of coronavirus named Middle East Respiratory Syndrome Coronavirus (MERS-CoV) was occurred (52). MERS-CoV mortality rate was 35\% (46), and it belonged to first lineage 2c Betacoronavirus (30). MERS-CoV was the second known zoonotic coronavirus with a high pathogenicity and its origin was assumed bats.

A novel coronavirus has been recently showed up in December 2019 in Wuhan, China. The virus causes a cluster of acute respiratory illness, and it has spread very quickly all around the world. The 2019 novel coronavirus (2019-nCoV) was identified from a patient's bronchoalveolar lavage fluid on January 2019. Full genome sequencing and phylogenic analysis revealed that 2019$\mathrm{nCoV}$ belongs to a distinct clade from the 
Betacoronaviruses associated with SARS-CoV and MERS-CoV (59). The name of the disease was given COVID-19 (abbreviation of coronavirus disease 2019) by WHO. Also, the International Committee on Taxonomy of Viruses (ICTV) termed the virus as SARS-CoV-2 and classified in the Betacoronavirus $2 \mathrm{~b}$ lineage same with SARS-CoV. It was reported that bats are the sources of the virus, and bat coronaviruses and SARS-CoV-2 have many similarities. Although the route of the SARS-CoV-2 has not been clearly stated, it has been suggested that contamination to humans from wild animals was happened because of illegally animal sale in the Huanan Seafood Wholesale Market (8). Today, SARS-CoV-2 is the seventh identified zoonotic coronavirus that infects humans along with SARS-CoV and MERS-CoV (47).

\section{COVID-19 chronology in Turkey}

Within ten days after the first COVID-19 (SARS$\mathrm{CoV}-2$ ) case was reported in Wuhan, China measures were started to take in Turkey. These measures can be classified under three subtitles such as; $i$ ) source oriented, ii) transmission route, and iii) safety of healthy person (35).

The first case was identified on March 11, 2020. After this date, local measures have been taken across the country to gradually prevent and reduce the spread of the virus in the society. Day by day, more serious precautions were started to taken such as closure of schools and universities, cancellation of international flights, limiting domestic transportation, curfew for people over 65 etc. The chronology of the measures was taken in the world and in our country after the first COVID-19 case are given in Table 1.

\section{Symptoms of SARS-CoV-2 Infection in humans}

Lungs are constantly in contact with the outside environment and these harsh conditions can drive lungs to be more protectionist in an inflammatory way. Also, host cells that under attacked of microorganisms become particularly more susceptible to genetic changes that help advance their evolution. This situation may cause enterocytes to play an important role in the coronavirus evolution. Under this kind of virus evolution, the only virus that can infect enterocytes can survive. It means that the evolved coronavirus should have a receptor-binding domain having a high binding affinity with the receptor on the membrane of enterocytes (14). Therefore, gastrointestinal (GI) manifestations are common features to the other members of the coronavirus family (11).

It has been previously reported that SARS-CoV effects the small intestine mucosa and cause enteric symptoms. There was a high prevalence of diarrhea (16$73 \%$ ) in the patients of SARS-CoV (24). Likewise, diarrhea and abdominal pain were common symptoms in patients of MERS-CoV (10). Studies showed the susceptibility of human intestinal cells to MERS-CoV infection previously (58). Symptoms such as nausea, vomiting, and diarrhea are seen in the SARS-CoV-2 similarly to SARS-CoV and MERS-CoV. Moreover, SARS-CoV-2 has respiratory clinical symptoms ranging from fever, dry cough, hemoptysis, and dyspnea to pneumonia. On the other hand, some of the patients get through this disease asymptomatically (9). Nevertheless, considering the severe respiratory clinical picture of SARS-CoV-2 pandemic, the biggest attention has been given to treatment of respiratory symptoms. However, the number of SARS-CoV-2 patients with diarrhea is quite high to ignore. The percentage of patients with diarrhea were reported ranging from $2 \%$ to $50 \%$ (11).

A meta-analysis study performed by Cheung et al. (9) was summarized the data of SARS-CoV-2 patients with GI manifestations. From six countries 4243 patients with anorexia, nausea/vomiting, diarrhea or abdominal pain included to the study and the prevalence of patients with GI symptoms was found $17.6 \%$. The prevalence of GI symptom, diarrhea, nausea/vomiting and abdominal pain/discomfort was reported $26.8 \%, 12.5 \%, 10.2 \%$ and $9.2 \%$, respectively. Also, it was shown that patients with GI symptoms tended to have severe clinical picture then those who had not. Hung et al. (21) reported that in the feces of $15.3 \%$ of patients the RNA of the virus was detected although some of the patients did not show any GI symptoms. In addition, the patients with no diarrhea had higher RNA and virus load in their feces compared to the ones with diarrhea. On the other hand, although very few, patients with constipation have also been reported (43).

It was reported that out of 99 of the 204 (48.5\%) SARS-Cov-2 positive patients were registered to the hospital due to the GI symptoms as their primary complaint. Respiratory symptoms were began to develop in 92 of these 99 patients along with GI problems, and seven were never had respiratory symptoms. Moreover, the patients with digestive symptoms were admitted to the hospital in a longer time period (9.0 days) than patients without GI symptoms (7.3 days). In these patients the prevalence of anorexia, diarrhea, vomiting and abdominal pain were reported as $83.8 \%, 29.3 \%, 0.8 \%$, and $0.4 \%$, respectively. In addition, patients without GI symptoms were tend to recover more quickly than those with digestive symptoms (60\% vs. 34.3\%) (29).

In the United States, it was stated that the first identified SARS-Cov-2 patient also had diarrhea (18). The feces sample was analyzed and the test gave positive result after 7 days of the onset of the disease with a high viral load. Xu et al. (50) reported that $9 \%$ of the patients who had symptoms for more than 10 days were showed diarrhea while the patients with no diarrhea were experienced a shorter disease duration. 
Table 1. COVID-19 measures chronology in Turkey after the first case $(33,35)$.

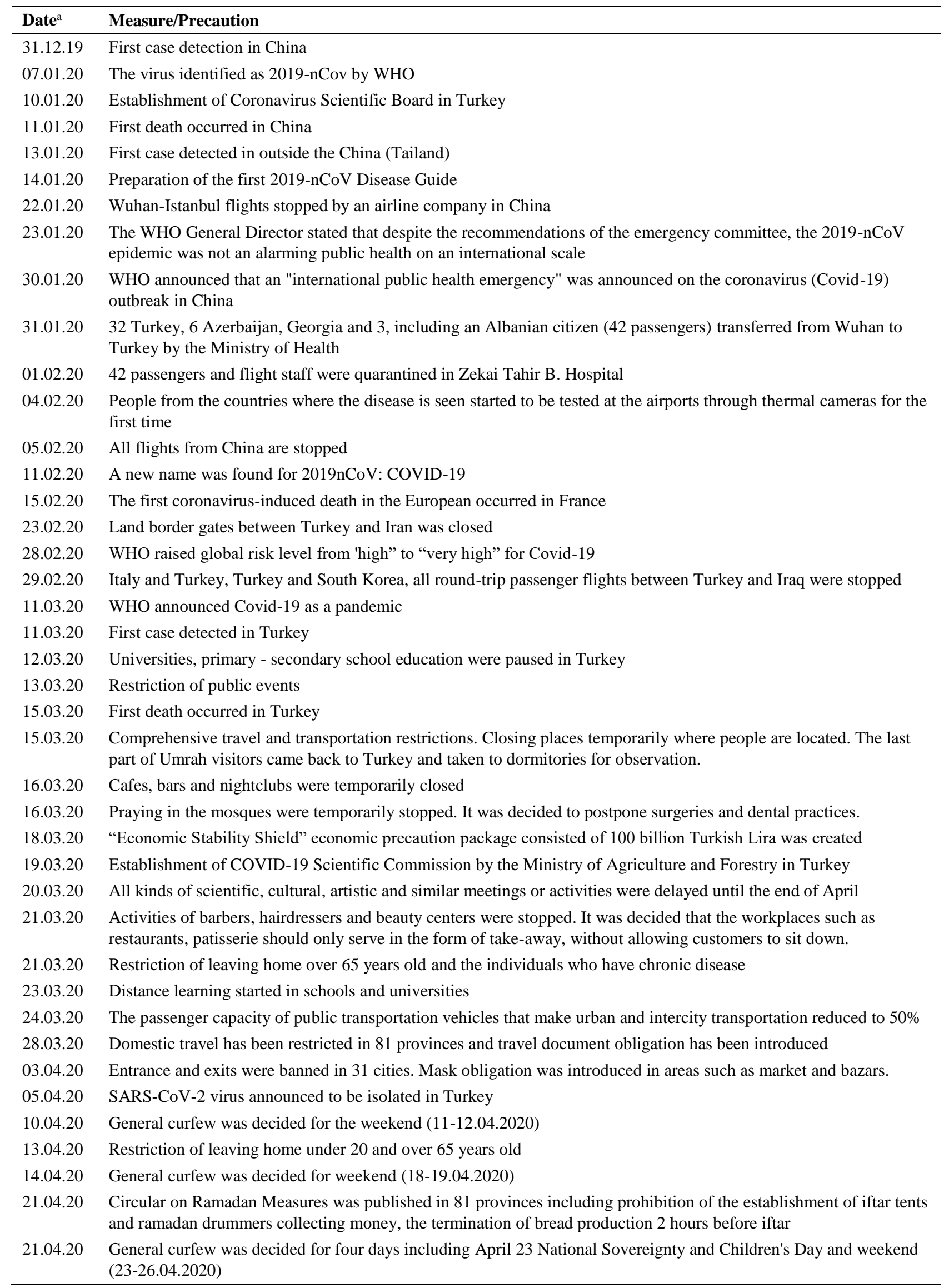

\footnotetext{
a Dates are given in the order of day, month, year.
} 
The possible reasons of why SARS-CoV-2 seems to cause GI symptoms were summarized by Pan et al. (28). First of all, the reason can be angiotensin converting enzyme-2 (ACE-2) receptor which is the entry point of SARS-CoV-2 to the human cells. ACE-2 receptor causes liver tissue injury by up-regulation of ACE-2 expression in liver, resulted in compensatory proliferation of hepatocytes derived from bile duct epithelial cells. Second reason can be inflammatory response. Viremia and inflammatory factors may damage the digestive system. Thirdly, the intestinal microbiota may be effected by the virus itself and this could end up with GI symptoms. This effect is called the "gut-lung axis". It comprises the immunological relationship between intestinal and respiratory tract. The changes in the intestine, the largest immune organ in the body, cause disorders in respiratory tract through immune regulation. The fact of SARS-CoV2 patients with pneumonia often show digestive symptoms may be explained with this effect.

Another phenomenon needed to be lighten if the SARS-CoV causes liver damage or not. Viral nucleic acids of the virus were found in liver tissue confirming that the virus can infect liver directly (7). However, SARSassociated hepatotoxicity may be a cause viral hepatitis or consumption of too many antiviral drugs or immune system response. Further investigations needed to be done to understand liver injury caused by SARS-CoV.

On the other side, some of the studies states that SARS-CoV-2 infection may be systemic. Wang et al. (40), reported that some blood samples were found positive by PCR suggesting in some patients SARS-CoV-2 may be systematic. Also, Zhang et al. (54) detected the virus in blood and oral/anal swabs in 16 patients, and Pan et al. (29) reported viral load in salvia and throat swabs in17 confirmed cases.

\section{Presence of COVID-19 in animals}

On April 22, 2020, the Centers for Disease Control and Prevention (CDC) reported that two cats were SARS-CoV-2 positive according to the test results approved by the American National Veterinary Services Laboratories (NVSL). These cats have been registered as the first pet animals identified as SARS-CoV-2 positive in the United States so far. It is stated that cats have mild respiratory symptoms but are in the process of recovery. However, this positivity does not mean that domestic animals are the source of coronavirus infection in humans (5).

In the light of the information obtained to date, two dogs and one cat have been reported positive in terms of SARS-CoV-2 previously in Hong Kong (2). Similarly, it is stated that a cat is positive in Belgium, but the data are not very clear. It is unclear whether the cat in Belgium carries another disease that may show the same clinical findings, and how samples collected from a positive animal were collected and evaluated (1). It has been reported that the owner of pets in Hong Kong has confirmed COVID-19 and is in close contact with their pets, while the animals do not show any clinical signs. Apart from pets, the SARS-CoV-2 positive sample was obtained from a tiger with signs of disease in the respiratory system in the New York Bronx Zoo in the United States on April 5, 2020. In the same zoo, four tigers and three lions showed dry cough and wheezing within one week, but animals did not develop dyspnea (breathing difficulties), runny nose or eye discharge. The source of infection in these animals is assumed to be an animal keeper carrying COVID-19 but without clinical signs (36).

In the light of the information and scientific data obtained until today; COVID-19 is transmitted from human to human contact, and there is no evidence that pets can spread COVID-19 disease to humans.

\section{Pathogenesis of SARS-CoV-2}

The interaction between the envelope-associated viral spike protein and the host receptor, consisting of ACE-2, mediates the SARS-CoV entry into the cell. The spike protein has two subunits; $\mathrm{S} 1$ intercedes the attachment of the virus to the cell membrane, and S2 helps the fusion of the two cell membranes. Serine proteases are needed for this process which regulates the whole mechanism by allowing spike protein cleavage (11). SARS-CoV-2 enters to the epithelial cells of respiratory and intestinal tracts via ACE-2 receptor as same as SARSCoV (37). Studies indicate that ACE-2 highly expressed in the lung AT2 cells as well as in esophagus epithelial cells and enterocytes of ileum and colon along (16). RNAsequencing data studies revealed the ACE-2 is highly expressed in the human small intestine, significantly in the proximal and distal enterocytes. In addition, the infectivity of the virus is determined by the binding affinity of ACE2 receptors $(25,37)$. Some studies showed that the new SARS-CoV-2 has a binding affinity for human ACE-2 1020 times stronger than SARS-CoV $(11,37)$. On the other hand, the RNA level of ACE-2 was found very low in the lung tissues interestingly, indicating small intestinal epithelium may be more vulnerable to attack by SARSCoV-2 (25). Therefore, intestinal epithelium may be damaged more due to the disruption of the ACE-2 function (ACE-2 modulates inflammation) and result in diarrhea (9).

Xiao et al. (49) demonstrated the viral nucleocapsid protein and ACE-2 protein expression in the human duodenal, rectal and gastric epithelial cells with intracellular staining, and consequently suggested that the ACE-2 receptors could be the entry point of the SARSCoV-2 in the intestinal tract. In another study, ANPEP receptor for $\mathrm{HCoV}-229 \mathrm{E}$ virus and DPP4 receptor for 
MERS-CoV virus (another two coronavirus receptors) were examined through of their expression profiles. According to RNA levels of the viruses it was determined that these two receptors were expressed highly in enterocytes, parallel with ACE-2's expression profile (25). Zhou et al. (58) reported that human intestines were susceptible to MERS-CoV because of the highly expression of the DPP4 receptor. Considering the related expression profiles of the ACE-2, ANPEP, and DPP4 receptors, the intestines of humans may be an alternative infection route for these viruses.

\section{Immune response to SARS-CoV-2}

SARS-CoV-2 display a less pathogenic profile then SARS-CoV. Although both of the viruses induce a strong cytokine response and therefore cause a pathogenic inflammation, the molecular pathways should be revealed to understand if there is an adaptation situation to humans. SARS-CoV suppresses the antiviral immunity and activates the proinflammatory response. On the other hand, SARS-CoV-2 do not harbor some interferon antagonists and inflammasome activators encoded by SARS-CoV-2 (51).

The clinical symptoms of SARS-CoV-2 are fever, dyspnea, pneumonia, diarrhea, and in some cases multiple organ failure. Lymphocytopenia is a common diagnostic indicator in patients. There are some reports state that the mortality rate is high in patients with low $\mathrm{CD}^{+}, \mathrm{CD}^{+}$, and $\mathrm{CD}^{+}$levels of lymphocytes $(53,57)$. The retrospective analyzes of the 34 patients with SARS-CoV2 in Zhongnan Hospital of Wuhan University showed that the $50 \%$ of the patients had a lymphopenia history (20). The laboratory findings of 33 SARS-CoV-2 patients were tracked back by Wang et al. (38). It was seen that the patients who died from this disease had an increase in neutrophil count, D-dimer, blood urea, and creatinine levels and a decrease in lymphocyte counts. MERS-CoV was also known to be associated with lymphopenia. Although MERS-CoV cannot replicate in T lymphocytes, it can directly infect primary $\mathrm{T}$ lymphocytes and resulting in T-cell apoptosis by triggering apoptosis pathways. Nevertheless, there is no clear evidence that SARS-CoV2 can infect $\mathrm{T}$ lymphocytes directly and cause lymphocytopenia (41). To investigate the susceptibility of T-cells to SARS-CoV-2 infection, Wang et al (41) replicate the $\mathrm{T}$-cell lines several times and found out that the sensitivity of T-cells to SARS-CoV-2 were significantly more than the SARS-CoV. The authors also suggested that $\mathrm{S}$ protein of SARS-CoV-2 may be had a role of mediating the infectivity, even with the cells of low hACE-2 expression, which can explain the high transmission rate of SARS-CoV-2. On the other hand, other receptors present on T lymphocytes (i.e. CD147 surface receptor on $\mathrm{T}$-cells) may have a role in mediating the entry the SARS-CoV-2 in to T lymphocytes (39).

\section{Detection methods for SARS-CoV-2}

There are various methods for the detection of diseases of viruses including SARS-CoV-2. These methods can be classified into four groups; nucleic acid, serology, CT imaging and blood test based methods (Table 2) (27).

Among the nucleic acid detection methods, quantitative real time polymerase chain reaction (qRTPCR) is the mainstream method for SARS-CoV-2 in Turkey and the world. In this method, specific fluorescent substances are added to the reaction. Hence, real time fluorescent can be detected and the results can be read through real time PCR device. With this method quantitative detection of SARS-CoV-2 can be performed (4).

The Next Generation Sequencing helps to characterize and understand the identification of the virus. Also, it can provide information about genomic changes of the virus and its transmission (27). The genome of SARS-CoV-2 was first published on January 24, 2020. Then, until April $21^{\text {st }}$ over 10.000 genomes of SARS-CoV2 have been shared through global initiative to share all influenza data (GISAID) and GenBank (44).

Table 2. Detection methods of COVID-19 (44).

\begin{tabular}{|c|c|c|c|}
\hline $\begin{array}{l}\text { SARS-CoV-2 Nucleic } \\
\text { Acid Detection }\end{array}$ & $\begin{array}{c}\text { SARS-CoV-2 Serology } \\
\text { Detection }\end{array}$ & Regular Blood Test & Chest CT Imaging \\
\hline - qRT-PCR & - ELISA & $\begin{array}{l}\text { Evaluation of the predictive } \\
\text { factor for COVID-19 }\end{array}$ & $\begin{array}{l}\text { The presence of bilateral } \\
\text { nodular and peripheral } \\
\text { ground glass opacities and } \\
\text { consolidation }\end{array}$ \\
\hline $\begin{array}{l}\text { - Next Generation } \\
\text { Sequencing }\end{array}$ & $\begin{array}{l}\text { - Chemiluminescent } \\
\text { immunoassay }\end{array}$ & $\begin{array}{l}\text { - Elevation in Lactic } \\
\text { Dehydrogenase (LDH) }\end{array}$ & \\
\hline $\begin{array}{l}\text { - Isothermal } \\
\text { Amplification }\end{array}$ & $\begin{array}{l}\text { - Immunologic colloidal gold } \\
\text { labelling }\end{array}$ & $\begin{array}{l}\text { Decrease in the lymphocytes } \\
\text { counts, especially in CD } 3^{+} \text {, } \\
\mathrm{CD} 4^{+} \text {and } \mathrm{CD} 8^{+} \mathrm{T} \text {-cells }\end{array}$ & \\
\hline - CRISPR & & & \\
\hline
\end{tabular}




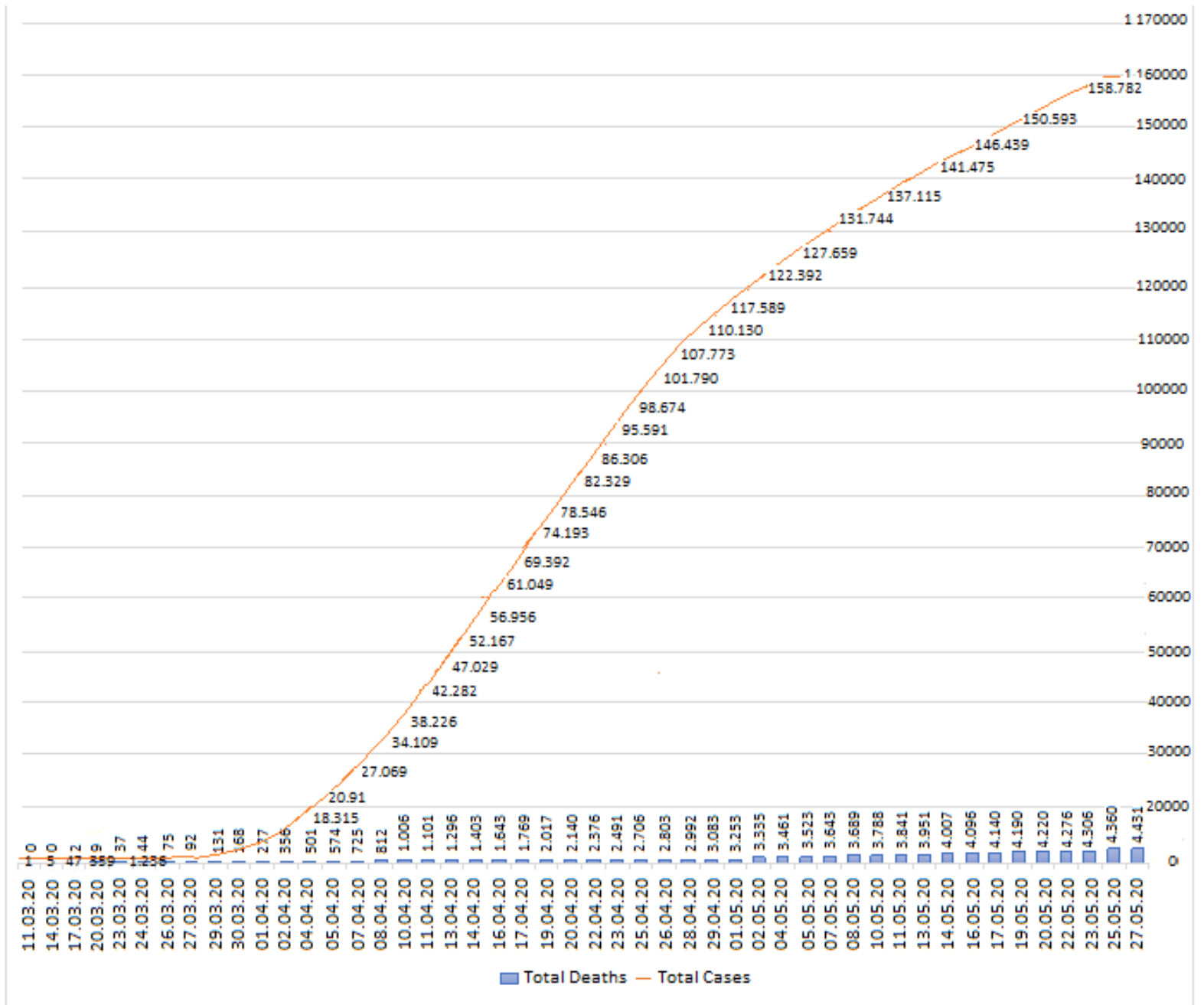

Figure 1. Cumulative COVID-19 cases and deaths in Turkey (33).

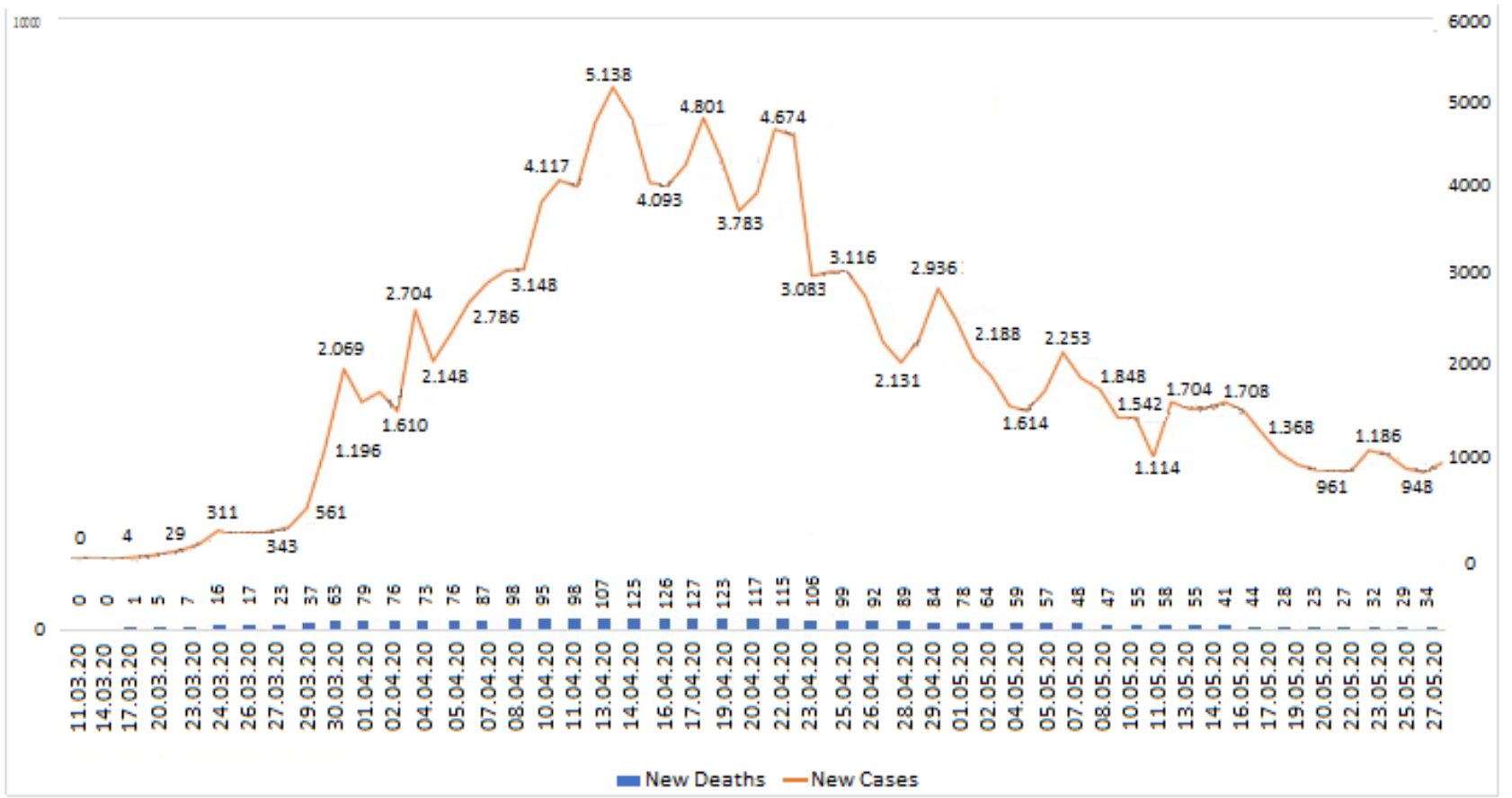

Figure 2. Number of daily new COVID-19 cases and deaths in Turkey (33). 
Table 3. Comparison of molecular methods (44).

\begin{tabular}{|c|c|c|c|c|}
\hline & \multicolumn{4}{|c|}{ Methods } \\
\hline & Sequencing & RT-qPCR & Isothermal Amplification & CRISPR \\
\hline Advantage & High accuracy & $\begin{array}{l}\text { High sensitivity and } \\
\text { specifity }\end{array}$ & Low cost for instrument & Detect DNA and RNA \\
\hline Disadvantage & $\begin{array}{l}\text { - High cost for } \\
\text { instrument } \\
\text { - Bioinformatics } \\
\text { expert needed } \\
\text { - Difficult for } \\
\text { widespread testing }\end{array}$ & $\begin{array}{l}\text { - High cost for instrument } \\
\text { - High false negative } \\
\text { results }\end{array}$ & $\begin{array}{l}\text { High needs for primer } \\
\text { design } \\
\text { - Non-specific binding of } \\
\text { primers can cause false } \\
\text { positive }\end{array}$ & $\begin{array}{l}\text { Should combine with } \\
\text { nucleic acid } \\
\text { amplification to } \\
\text { increase the sensitivity }\end{array}$ \\
\hline
\end{tabular}

Table 4. Comparison of nucleic acid and serological methods (44).

\begin{tabular}{lll}
\hline & \multicolumn{1}{c}{ Nucleic acid } & \multicolumn{1}{c}{ Methods } \\
\cline { 2 - 3 } Advantage & High sensitivity and specifity & Very fast, low cost and specific instrument is not required \\
\hline \multirow{3}{*}{ Disadvantage } & $\bullet$ False negative results & $\bullet$ Sensitivity and specifity limitation \\
& & $\bullet$ Negative results in early stage of infection \\
\hline
\end{tabular}

Isothermal amplification method has also been proven for SARS-CoV-2 detection. With this method, the same sensitivity and specifity with qRT-PCR for the detection of SARS-CoV-2 can be achieved. The use of only one temperature for the amplification and low instrument requirement is the main advantages (56). One of the other method for the detection of SARS-CoV-2 virus is Clustered Regularly Interspaced Short Palindromic Repeats (CRISPR). This method utilizes CRISPR-CAS12 or CAS13 based RNA technology and requires to convert RNA to cDNA (19). The advantages and disadvantages of the molecular methods are given in Table 3.

SARS-CoV-2 can also be detected by serological tests which are essential to better understand the epidemiology of SARS-CoV-2. They can be used to confirm the infection (48). These methods are accurate, rapid and simple test methods to quickly identify large number of infected patients and asymptomatic carriers to prevent from virus transmission and assure timely treatment of patients (54). The advantages and disadvantages of serological methods are compared with nucleic acid detection methods in Table 4.

Serological methods provide detection of antibodies or antigens. Using antibodies specific to the surface antigens, SARS-CoV-2 virus can be detected from a direct measurement of oral or nasal swab or broncho-alveolar fluid. On the other hand, specific antigens can be used for the detection of IgM or IgG antibodies against SARSCoV-2 by a direct analyze on blood serum of patients (44, 48).
In Turkey for the detection of SARS-CoV-2 infection nasopharyngeal swabs of patients are being testing with qRT-PCR method because of the high sensitivity and specifity of the unique primers and oligonucleotide probes marked with fluorescent dyes. In addition to the PCR results, symptoms, risk factors, pneumonia findings and thorax CT scans are evaluated together in the diagnosis of the disease $(34,35)$.

\section{Potential fecal-oral transmission}

Enteric viruses primarily transmitted through fecaloral route due to consumption of contaminated food and water, or by person to person contact as a secondary route. The major transmitters were identified in many studies as human feces, sewage, infected food handlers, animals and their waste. Gastroenteritis and hepatitis are the most common symptoms of enteric foodborne viruses. Patients can shed the extremely high number of virus particles through their stools before / after the onset of symptoms. Moreover, people who are infected but show no symptoms can transmit viruses without knowing $(3,13)$.

Sewage systems can be considered as an important source in transmission of coronavirus. In 2003, during SARS-CoV outbreak Lee (23) reported that the sewage system in Hong Kong served as a reservoir as the sewage system harbored SARS-CoV patients' feces. In the same period the sewage system of two hospitals were also found to have SARS-CoV RNA in Beijing (42). Chan et al. (6) stated that fecal shedding of SARS-CoV RNA could persist until 30 days and more. 
A further confirmation of possible fecal-oral transmission reveals when considering the homology between these three coronaviruses (SARS-CoV-2, SARS$\mathrm{CoV}$ and MERS-CoV), with the tolerance of low temperatures up to two weeks and capacity of survival between $20-30^{\circ} \mathrm{C}$ (11). The prolonged persistence of SARS-CoV-2 in the stool compared to respiratory tract swabs serves strong clinical evidence that fecal-oral transmission is probable $(11,16)$. Cheung et al. (9) reported that although $70.3 \%$ of the patients' stool tests were remained positive for SARS-CoV-2 RNA, their respiratory tract samples were found negative. In addition, Zhang et al. (55) confirmed the presence of live virus in stool samples, that is to say stool can contaminate food, water, hands etc. and cause infection. Although these results strengthening the hypothesis that the virus can spread by fecal-oral route, it is still not proved.

Currently, GI infections in which coronavirus is involved are present in humans (15). For example, Torovirus, which is detected in cases of gastroenteritis in humans, is a member of the Coronaviridae subfamily. The virus, shares a similar genomic sequence with Coronaviruses about $25-30 \mathrm{~kb}$ in length. It is a singlestranded RNA virus with 100-150 nm diameter, enveloped, positive polarity (32). In studies related to Torovirus, it is stated that the virus was detected in patients who developed enteritis. Jamieson et al. (22) reported that Torovirus was isolated in $35 \%$ of 206 people with gastroenteritis and encountered as the most common viral gastroenteritis agent. In another study, Torovirus was detected as the predominant virus in nosocomial viral gastroenteritis in Canada (31). Similarly, Gubbay et al. (17) stated that $67 \%$ of 133 children with gastroenteritis were found to be positive for Torovirus in Toronto, Canada. Rotarovirus (19\%) and Adenovirus (9\%) were detected as the other predominant viruses after Torovirus, respectively. Torovirus has been identified as an important gastroenteritis agent especially in children. Considering that children can carry SARS-CoV-2 asymptomatically, the possibility that it may appear as a problem in the future should be considered.

\section{Conclusion}

SARS-CoV-2 is a highly contagious agent therefore, people should avoid contact with possible contamination sources and should pay great attention to hygiene rules. Although SARS-CoV-2 shows high homology with SARS-CoV and MERS-CoV, it transmits faster than those two coronaviruses which demonstrates the importance of a rapid and optimized analysis. The presence of SARSCoV-2 RNA in stool is a significant evidence of the fecaloral route which should not be ignored. Understanding the route of infection is essential to control infections in hospitals and society. Also, the viral shedding dynamics in various systems are needed to be further investigated.

The alarming presence of diarrhea in patients with SARS-CoV-2 infection should not be underestimated. People admitted to the hospitals with diarrhea should be considered as a possible SARS-CoV-2 patient and should further investigated in order to reach early diagnosis of the disease. If the clinicians only focus on the respiratory symptoms, they are likely to miss extra respiratory symptoms, and consequently patients with SARS-CoV-2 could gone unnoticed. Therefore, early diagnostic approaches and therapeutic interventions are needed to be studied as well as the pathogenesis of the virus.

\section{Acknowledgements}

The authors, Prof. Dr. Muammer Göncüoğlu and Prof. Dr. Naim Deniz Ayaz are members of COVID-19 Scientific Commission of the Ministry of Agriculture and Forestry in Turkey.

\section{Financial Support}

This review received no grant from any funding agency/sector.

\section{Ethical Statement}

This study does not present any ethical concerns.

\section{Conflict of Interest}

The authors declared that there is no conflict of interest.

\section{References}

1. Anonymous (2020): A cat appears to have caught the coronavirus, but it's complicated. Science News. Available at: https://www.sciencenews.org/article/cats-animals-petscoronavirus-covid19 (Accessed April 28, 2020).

2. Anonymous (2020): Pet dog tests positive for COVID-19 virus: The government of the Hong Kong Special administrative region-press release. Available at: https://www.info.gov.hk/gia/general/202003/19/P2020031 900606.htm (Accessed April 22, 2020).

3. Bosch A, Gkogka E, Le Guyader FS, et al (2018): Foodborne viruses: Detection, risk assessment, and control options in food processing. Int J Food Microbiol, 285, 110128.

4. CDC (2020): 2019-Novel Coronavirus (2019-nCoV) RealTime RT-PCR diagnostic panel; division of viral diseases. Available at: https://www.fda.gov/media/134922/download (Accessed April 15, 2020).

5. CDC (2020): Confirmation of COVID-19 in two pet cats in New York. Available at: https://www.cdc.gov/media/ releases/2020/s0422-covid-19-cats-NYC.html (Accessed April 24, 2020).

6. Chan KH, Poon LL, Cheng VCC, et al (2004): Detection of SARS coronavirus in patients with suspected SARS. Emerging Infect Dis, 10, 294. 
7. Chau TN, Lee KC, Yao H, et al (2004): SARS-associated viral hepatitis caused by a novel coronavirus: report of three cases. Hepatol, 39, 302-310.

8. Chen N, Zhou M, Dong X, et al (2020): Epidemiological and clinical characteristics of 99 cases of 2019 novel coronavirus pneumonia in Wuhan, China: a descriptive study. Lancet, 395, 507-513.

9. Cheung KS, Hung IF, Chan PP, et al (2020): Gastrointestinal manifestations of SARS-CoV-2 infection and virus load in fecal samples from the hong kong cohort and systematic review and meta-analysis. Gastroenterology, In press, https://doi.org/10.1053/j.gastro.2020.03.065.

10. Choi WS, Kang CI, Kim Y, et al (2016): Clinical presentation and outcomes of Middle East respiratory syndrome in the Republic of Korea. Infect Chemother, $\mathbf{4 8 ,}$ 118-126.

11. D'Amico F, Baumgart DC, Danese S, et al (2020): Diarrhea during COVID-19 infection: pathogenesis, epidemiology, prevention and management. Clin Gastroenterol Hepatol, In press, https://doi.org/10.1016/j.cgh.2020.04.001.

12. Drosten C, Günther S, Preiser W, et al (2003): Identification of a novel coronavirus in patients with severe acute respiratory syndrome. $\mathrm{N}$ Engl J Med, 348, 19671976.

13. EFSA (2011): Scientific opinion on an update on the present knowledge on the occurrence and control of foodborne viruses. EFSA J, 9, 2190.

14. Feng Z, Wang Y, Qi, W (2020): The small intestine, an underestimated site of SARS-CoV-2 infection: from red queen effect to probiotics. Preprints 2020, 2020030161.

15. Goncuoglu M, Onaran B, Cengiz G (2018): Kobuvirus, Torovirus ve Picobirnavirus. Turkiye Klinikleri J Food Hyg and Technol-Special Topics, 4, 37-44.

16. Gu J, Han B, Wang J (2020): COVID-19: gastrointestinal manifestations and potential fecal-oral transmission. Gastroenterology, 158, 1518-1519.

17. Gubbay JB, Al-Rezqi A, Hawkes M, et al (2012): The role of torovirus in nosocomial viral gastroenteritis at a large tertiary pediatric centre. Can J of Infect Dis Med, 23, 7881.

18. Holshue ML, DeBolt C, Lindquist S, et al (2020): First case of 2019 novel coronavirus in the United States. N Engl J Med, 382, 929-936.

19. Hou T Zeng W, Yang M, et al (2020): Development and evaluation of a CRISPR-based diagnostic for 2019-novel coronavirus. MedRxiv, In press, https://doi.org/10.1101/2020.02.22.20025460.

20. Huang Y, Tu M, Wang S, et al (2020): Clinical characteristics of laboratory confirmed positive cases of SARS-CoV-2 infection in Wuhan, China: a retrospective single center analysis. Travel Med Infect Dis, 101606.

21. Hung IF, Cheng VC, Wu AK, et al (2004): Viral loads in clinical specimens and SARS manifestations. Emerg Infect Dis, 10, 1550- 1557.

22. Jamieson FB, Wang EE, Bain C, et al (1998): Human torovirus: a new nosocomial gastrointestinal pathogen. Infect Dis, 178, 1263-1269.

23. Lee SH (2003): The SARS epidemic in Hong Kong. $\mathrm{J}$ Epidemiol Community Health, 57, 652-654.
24. Leung WK, To KF, Chan PK, et al (2003): Enteric involvement of severe acute respiratory syndromeassociated coronavirus infection. Gastroenterol, 125, 10111017.

25. Liang W, Feng, Z, Rao, S, et al (2020): Diarrhoea may be underestimated: a missing link in 2019 novel coronavirus. Gut, 69, 1141-1143.

26. Memish ZA, Assiri A, Alhakeem R, et al (2014): Middle East respiratory syndrome corona virus, MERS-CoV. conclusions from the 2nd scientific advisory board meeting of the WHO collaborating center for mass gathering medicine, Riyadh. Int J Infect Dis, 24, 51-53.

27. Miller S, Chiu C, Rodino KG, et al (2020): Pointcounterpoint: should we be performing metagenomic nextgeneration sequencing for infectious disease diagnosis in the clinical laboratory? J Clin Microbiol, 58, e01739-19.

28. Pan L, Mu M, Yang P, et al (2020): Clinical characteristics of COVID-19 patients with digestive symptoms in Hubei, China: a descriptive, cross-sectional, multicenter study. Am J Gastroenterol, 115, 766-773.

29. Pan Y, Zhang D, Yang P, et al (2020): Viral load of SARSCoV-2 in clinical samples. Lancet Infect Dis, 20, 411-412.

30. Raj VS, Osterhaus A D, Fouchier RA, et al (2014): MERS: emergence of a novel human coronavirus. Curr Opin Virol, 5, 58-62.

31. Stegenga J, Bell E, Matlow A (2002): The role of nurse understaffing in nosocomial viral gastrointestinal infections on a general pediatrics ward. Infect Control Hosp Epidemiol, 23, 133-136.

32. Sun H, Lan D, Lu L, et al (2014): Molecular characterization and phylogenetic analysis of the genome of porcine torovirus. Arch Virol, 159, 773-778.

33. T.C. Sağlık Bakanlı̆̆ı (2020): COVID-19, Türkiye'deki güncel durum. Available at: https://covid19.saglik.gov.tr/. (Accessed April 15, 2020).

34. T.C. Sağlık Bakanlığı (2020): Halk Sağlığı Genel Müdürlügü, Covid-19 (SARS-CoV-2) rehberi (Bilim Kurulu Çalışması). Available at: https://covid19bilgi. saglik.gov.tr/depo/rehberler/Covid-19_Rehberi.pdf. (Accessed April 15, 2020).

35. TÜBA (2020): COVID-19 Pandemi değerlendirme raporu. Available at: http://www.tuba.gov.tr/tr/yayinlar/suresizyayinlar/raporlar/covid-19-pandemi-degerlendirme-raporu (Accessed April 15, 2020).

36. USDA (2020): USDA Statement on the confirmation of COVID-19 in a Tiger in New York. Available at: https://www.aphis.usda.gov/aphis/newsroom/news/ (Accessed April 23, 2020).

37. Wan Y, Shang J, Graham R, et al (2020): Receptor recognition by the novel coronavirus from Wuhan: an analysis based on decade-long structural studies of SARS coronavirus. J Virol, 94, e00127-20

38. Wang D, Hu B, Hu C, et al (2020): Clinical characteristics of 138 hospitalized patients with 2019 novel coronavirusinfected pneumonia in Wuhan, China. Jama. 323, 10611069.

39. Wang K, Chen W, Zhou YS, et al (2020): SARS-CoV-2 invades host cells via a novel route: CD147-spike protein. bioRxiv, 988345 . 
40. Wang W, Xu Y, Gao R, et al (2020): Detection of SARSCoV-2 in different types of clinical specimens. Jama, 323, 1843-1844.

41. Wang X, Xu W, Hu G, et al (2020): SARS-CoV-2 infects T lymphocytes through its spike protein-mediated membrane fusion. Cell Mol Immunol, In press, https://doi.org/10.1038/s41423-020-0424-9.

42. Wang XW, Li J, Guo T, et al (2005): Concentration and detection of SARS coronavirus in sewage from Xiao Tang Shan Hospital and the 309th Hospital of the Chinese People's Liberation Army. Water Sci Technol, 52, 213-221.

43. Wang Z, Chen X, Lu Y, et al (2020): Clinical characteristics and therapeutic procedure for four cases with 2019 novel coronavirus pneumonia receiving combined Chinese and Western medicine treatment. Biosci Trends, 14, 64-68.

44. Wong E (2020): Detection method for COVID-19 and vaccine development progress. GenScript Webinar April 9th, 2020. Available at: https://www.genscript.com/ webinars/detection-method-for-covid-19-and-vaccinedevelopment-progress.html. (Accessed April 10, 2020).

45. WHO (2003): Consensus document on the epidemiology of severe acute respiratory syndrome (SARS). Available at: http://www.who.int/csr/sars/en/WHOconsensus.pdf. (Accessed April 15, 2020).

46. WHO (2014): Middle East respiratory syndrome coronavirus (MERS-CoV) summary and literature update as of 26 June 2014. Available at: http://www.who.int/ csr/don/2014_06_26_mers/en/. (Accessed April 15, 2020).

47. Wu F, Zhao S, Yu B, et al (2020): A new coronavirus associated with human respiratory disease in China. Nature, 579, 265-269.

48. Xiang J, Yan M, Li H, et al (2020): Evaluation of enzymelinked immunoassay and colloidal goldimmunochromatographic assay kit for detection of novel coronavirus (SARS-Cov-2) causing an outbreak of pneumonia (COVID-19). medRxiv, In press, https://doi.org/10.1101/2020.02.27.20028787.
49. Xiao F, Tang M, Zheng X, et al (2020): Evidence for gastrointestinal infection of SARS-CoV-2. Gastroenterology, 158, 1831-1833.

50. Xu XW, Wu XX, Jiang XG, et al (2020): Clinical findings in a group of patients infected with the 2019 novel coronavirus (SARS-Cov-2) outside of Wuhan, China: retrospective case series. BMJ, 368, m606.

51. Yuen KS, Ye ZW, Fung SY, et al (2020): SARS-CoV-2 and COVID-19: The most important research questions. Cell Biosci, 10, 1-5.

52. Zaki AM, Van Boheemen S, Bestebroer TM, et al (2012): Isolation of a novel coronavirus from a man with pneumonia in Saudi Arabia. N Engl J Med, 367, 1814-1820.

53. Zeng Q, Li YZ, Huang G, et al (2020): Mortality of COVID-19 is associated with cellular immune funct2020ion compared to immune function in Chinese Han population. medRxiv, In press, https://doi.org/10.1101/ 2020.03.08.20031229

54. Zhang W, Du RH, Li B, et al (2020): Molecular and serological investigation of 2019-nCoV infected patients: implication of multiple shedding routes. Emerg Microbes Infect, 9, 386-389.

55. Zhang Y, Chen C, Zhu S, et al (2020): Isolation of 2019$n C o V$ from a stool specimen of a laboratory-confirmed case of the coronavirus disease 2019 (COVID-19). China CDC Weekly, 2, 123-4.

56. Zhang Y, Odiwuor N, Xiong J, et al (2020): Rapid molecular detection of SARS-CoV-2 (COVID-19) virus RNA using colorimetric LAMP, medRxiv, In press, https://doi.org/10.1101/2020.02.26.20028373.

57. Zheng M, Gao Y, Wang G, et al (2020): Functional exhaustion of antiviral lymphocytes in COVID-19 patients. Cell Mol Immunol, 17, 533-535.

58. Zhou J, Li C, Zhao G, et al (2017): Human intestinal tract serves as an alternative infection route for Middle East respiratory syndrome coronavirus. Sci Adv, 3, eaao4966.

59. Zhu N, Zhang D, Wang W, et al (2020): China novel coronavirus investigating and research team. A novel coronavirus from patients with pneumonia in China, 2019. N Engl J Med, 382, 727-733. 